\title{
A review of the identification methods and types of collapsible soils
}

\author{
Alfred Wilson Opukumo ${ }^{1 *}$, Colin T. Davie ${ }^{2}$, Stephanie Glendinning ${ }^{2}$ and Ebiegberi Oborie ${ }^{1}$
}

\author{
* Correspondence: alfred. \\ opukumo@gmail.com \\ 'Department of Geology, Niger \\ Delta University, Wilberforce Island, \\ Amassama, Bayelsa State, Nigeria \\ Full list of author information is \\ available at the end of the article
}

\begin{abstract}
Collapsible soils have caused infrastructural damages resulting in several economic losses and loss of lives in certain cases. The prerequisite for collapse occurring is an open metastable structure; capable of developing in any soil type given the right placement or aging conditions. Natural and anthropogenic (engineered and nonengineered) collapsible soils exist in many regions of the world. In their unsaturated state, these soils exhibit high enough shear strength and stiffness (provided by interparticle bonds of either suction, clay, calcium carbonate, or other salts) but upon wetting and/or loading they undergo repacking due to bond softening/weakening. This collapse of the soil structure leads to a rapid volume decrease and consequently associated issues such as rapid differential settlement, ground fissuring and landslides occur causing damages to civil structures, and loss of lives. Despite these threats and the large body of research available in this subject, there is still poor understanding of the process of softening/weakening and the collapse mechanism of certain bond in some collapse elements. The aim of this paper is to provide a state-of-the-art comprehensive review of the different types of collapsible soils, field, and laboratory methods of predicting and measuring their potential to collapse. This understanding is crucial for geotechnical characterisation of soils in order to design safe and economic infrastructures with their long-term serviceability also in focus.
\end{abstract}

Keywords: Collapse potential, Engineered and non-engineered soils, Field prediction, Laboratory prediction

\section{Introduction}

In geotechnical engineering, several soils are considered problematic because of their undesirable behaviour. The characteristics of a soil depend on their origin and mode of formation, their composition, their mineralogy, the nature of their pore fluids, or their fabric [12, 47]. Some of the most problematic geomaterials are the moisture sensitive ones, e.g. expansive clays and collapsible soils [27, 47]. This study focuses on collapsible soils. It reviews available knowledge on the behaviour and features of natural and artificial collapsible soils, the analytical and empirical techniques used to predict and classify collapsibility in unsaturated soils.

(c) The Author(s). 2022 Open Access This article is licensed under a Creative Commons Attribution 4.0 International License, which permits use, sharing, adaptation, distribution and reproduction in any medium or format, as long as you give appropriate credit to the original author(s) and the source, provide a link to the Creative Commons licence, and indicate if changes were made. The images or other third party material in this article are included in the article's Creative Commons licence, unless indicated otherwise in a credit line to the material. If material is not included in the article's Creative Commons licence and your intended use is not permitted by statutory regulation or exceeds the permitted use, you will need to obtain permission directly from the copyright holder. To view a copy of this licence, visit http://creativecommons.org/licenses/by/4.0/. The Creative Commons Public Domain Dedication waiver (http://creativecommons.org/publicdomain/zero/1.0/) applies to the data made available in this article, unless otherwise stated in a credit line to the data. 
Collapse has been defined as a mechanism of sudden reduction in total volume of a metastable soil structure (i.e. an open structure) under certain loading and/or wetting conditions. These soils are usually capable of sustaining substantial high-applied vertical stress in their in situ conditions without significant volume change but when wetted, undergo rapid and large reduction in volume [2, 4, 7, 36, 34, 48]. Collapse is believed to occur when the particle-to-particle bonding is destroyed by wetting with or without additional loading, thus an initial open structure becomes dense [22, 45, 48]. Collapsible soils are extremely common globally, presenting structural and geotechnical engineering problems. They form through both natural processes and human activity, and in either cases an open metastable structure (supported by inter-particle bonding) is the main prerequisite to collapse (Dudley, 1970 in Jefferson and Rogers [29]). However, they are known to be stiff and exhibit high strength in their unsaturated state [49]. Huge loses (economic and lives) have resulted from collapsible soils [18, 27, 51, 53]. Therefore, for a geotechnical engineer to be able to prevent such loses, by way of providing economic and efficient engineering solutions, four steps are recommended [46] to follow: (i) identification-determine the existence of a collapsible soil; (ii) classification-if a collapsible soil exists, what is the significance? (iii) quantification-what is the degree of collapse that will occur? (iv) evaluation-what are the design options? However, Houston et al. [27] recognised that the greatest problems with collapsible soils result from not recognizing the existence and extent of their collapse potential (CP) prior to construction.

Collapse is usually triggered either naturally through flooding/groundwater rise and/ or loading (e.g. earthquakes), or artificially by human activity. Human activity can be either unintentional via poor drainage control (e.g. broken water or sewer lines, landscape irrigation, poor surface drainage, roof runoff, etc.), or deliberate through ground improvement, e.g. dynamic compaction [26, 27, 29]. Unlike consolidation where the reduction in volume (or void ratio) is the consequence of time-dependent discharge of excess pore water, the reduction in volume for a collapsing soil is rapid and the result of water ingress into the soil and/or bond breaking caused by increased stresses [30].

Collapsible soils are known to exhibit certain physical and structural features such as an open and potentially metastable structure, an unsaturated state, high void ratio and porosity, low dry density, enough particle-to-particle bonding agent to hold particles together in their unsaturated state $[7,48]$. Their mineralogy spans a wide range but particles usually varying between sand and clay sizes. Capillary water, clay minerals, calcium carbonate and other soluble salts have been argued to play a role in the formation of bonding between elements, providing the initial stability in these metastable soils [29, $43,45,48,49]$. However, wetting, eliminates this bonding and sudden restructuring occurs (cited in [36, 39, 49].

Notwithstanding the problems associated with collapsible soils, the extension of cities and construction of new earthwork infrastructure all over the world, as well as the concept of sustainable construction has made it almost inevitable for collapsible geomaterials being utilised as either host or fill materials $[44,53]$ despite warnings, e.g., from code of practice for foundations (British Standard, BS 8004:1986) [53]. However, because of the geotechnical challenges and losses experienced from these problematic soils, extensive research works on their mechanical behaviours and methods of mitigating these problems have been carried out over many decades [18, 27, 30, 32, 51]. This 
review, thus, intends to provide further understanding of the problem by presenting a compilation of different research perspectives to the issue.

\section{Main text}

\section{Economic loses from soil collapse}

Soil collapse has contributed to serious damage to infrastructure built with or hosted on metastable soils. This damage appears as cracks or sometimes complete breaking of infrastructure beyond their serviceability limit leading to economic loses and even loss of lives in some instances $[18,27,51]$. Houston et al. [27] noted collapsible soils as being the most problematic geomaterial in the context of geotechnical engineering. Considering reports in the literature $[27,30,35]$, it is possible that globally, economic losses of the order of several billions of dollars may result from these geomaterials each year. For instance, in 1992 (Lawton et al.) estimated over US\$100 million of costs resulting from infrastructural damages and litigations caused by collapses in a few cases they reported on in Southern California. Estimates of damage over recent decades exceeding US\$100 million were recorded to result from collapsible loess in Bulgaria (Minkov, 1993 in Jefferson et al. [30]). A commercial building in New Mexico suffered a foundation damage due to soil collapse after heavy watering, causing about US\$0.5 million loses [27]. Beside these, there are several unquantified losses caused by soil collapse, e.g. Watts and Charles [53] reported huge damages to numerous infrastructures founded on different kinds of non-engineered fills.A few examples of infrastructural damages caused by collapsible soils are listed in Table S1 in the Supplementary Material.

\section{Origin and forms of collapsible soils}

Rogers [48] broadly classify collapsible soils into manmade and natural types cutting across soils from nearly all origins (see Fig. 1). Manmade being typically poorly

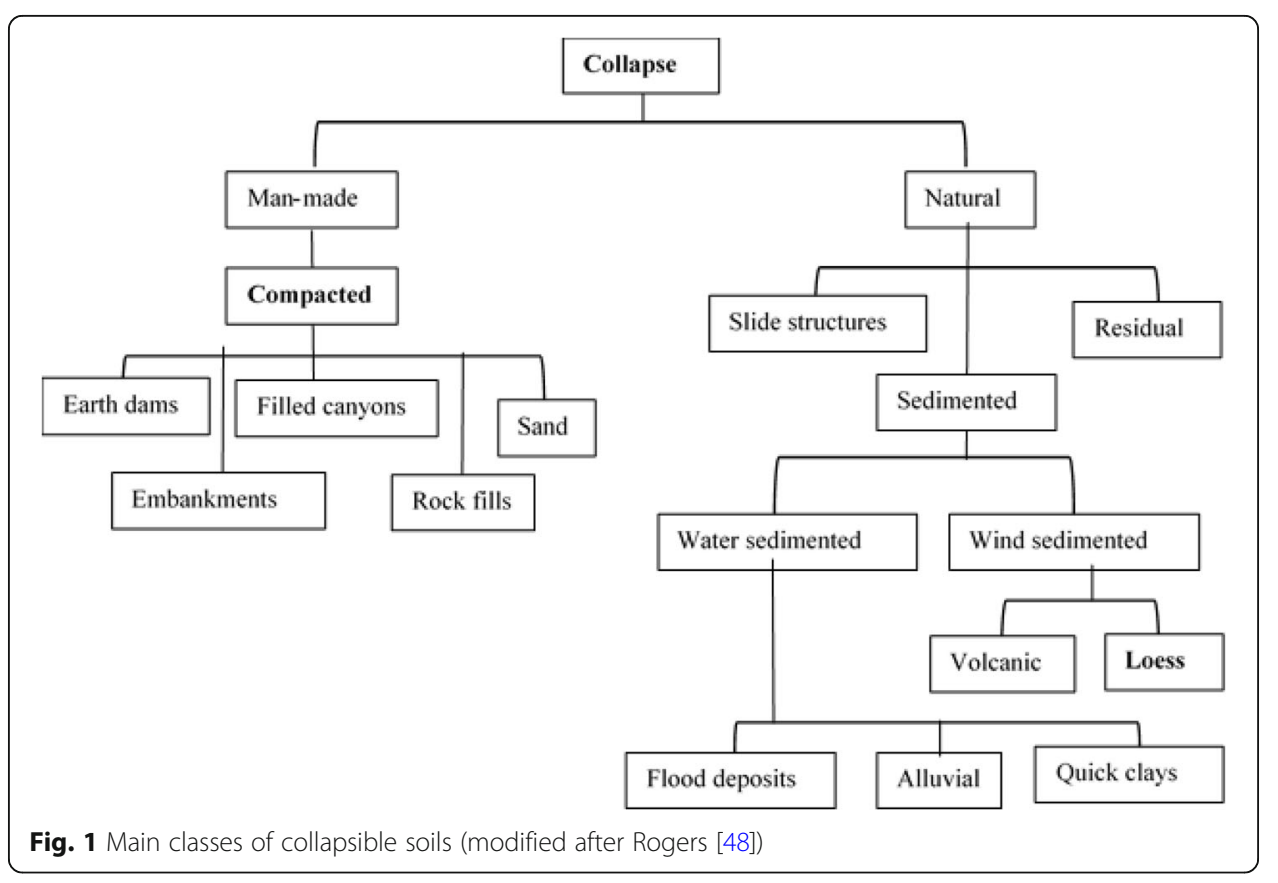


engineered (compacted) or non-engineered soils. The most common types of natural collapsible soils according to the University of Iowa 2002 [39] are: water (alluvial), wind (aeolian), and gravity (colluvial) deposits, and residual (from extensive weathering of parent rock) soils. They range from clays, silts, loess, volcanic ash tuffs, and fine sands $[38,39]$.

\section{Manmade (engineered and non-engineered) collapsible soils}

Anthropogenic collapsible soils arise from poorly engineered and non-engineered fills [39, 48, 53]. As corroborated by Rogers [48], Lawton et al. [35] had reported many cases of significant damages to earthworks related to soil collapse in compacted fills since 1953. Lawton et al. [35] went further to state that there had been a mistaken belief that precludes the possibility of further densification of compacted fills even upon access to water, and that this belief could have been responsible for damages recorded.

From their review, they observed that nearly all kinds of compacted soils are subject to collapse under certain loading and environmental conditions. Whether clean sands or pure clays (including montmorillonite) or soils with significant gravel fractions. Damages caused by collapse in compacted fills included damage to pavements and subgrades placed on highway embankments, cracking and slope failure within fills (piping, seepage losses, and failure in earth dams), damage to foundations and structures placed on fills, and distress or failure of underground utilities [3, 4, 7, 27, 35, 48].

Some case histories of collapse of compacted fills reported in Lawton et al. [35] are: two low earth dams constructed in Western Canada in the late 1930s and early 1940s that failed due to collapse. Cracking in three earth dams located in California were found to be due to differential settlement resulting from collapse. Wetting induced collapse was reported as key factor of the 1976 collapse of the Teton Dam in Idaho. Others were collapse of earth dams in the semiarid region of northeast Brazil caused by piping resulting from cracks induced by wetting, and a few instances of deformation, cracking, and failure of highway embankments in South Africa resulting from wettinginduced settlement (collapse settlement).

Other wetting-induced collapse cases which Lawton and colleagues were involved as forensic investigators in the early 1980s were in southern California, where a compacted fill placed in a canyon failed resulting in damages and litigations worth over 30 million dollars. Cox 1978 mentioned how important the National House Builders Council of Great Britain considered the problem of collapse settlement of floor slabs placed on fill by discussing it in their 1977 Guidance Notes for House Construction. There were reviews of these failures which reveal that some of them were compacted on the dry side of optimum with low levels of saturation and low dry densities, and with light compactive efforts. Wetting could have occurred from infiltration of water following periods of heavy rainfall, ineffective drainages, regional groundwater build-up, broken water pipes, ponding, flooding, moisture build-up beneath covered areas, irrigation, etc. [34].

Watts and Charles [53] have also discussed extensively the collapse behaviour of fills, in their book "building on fill: geotechnical aspects," a BRE publication. They recognised generally two forms of fills: engineered and non-engineered fills. According to Watts 
and Charles [53], engineered fills are the fills selected, placed and compacted in controlled conditions to achieve specification, so that they exhibit engineering behaviour adequate for their purpose, while non-engineered fills arise as by-products of human activities involving the disposal of waste materials with no subsequent engineering application in sight. However, both fill types may constitute either natural soils and rocks or several forms of waste material placed over natural ground. Some waste materials, particularly found in the UK include opencast mining backfill, colliery spoil, urban fill, domestic refuse, industrial and chemical wastes, pulverised fuel ash, hydraulic fill, infilled docks, pits, and quarries, etc.

Despite that engineered fills may also exhibit some collapse behaviour under certain conditions. Watts and Charles [53] believe that most of the collapse problems encountered with fill deposits are associated with construction on non-engineered fills. This is particularly due to their variability, differential movements, and the difficulty to characterise them.

A few examples of buildings founded on fills and damaged by the collapse phenomenon as reported in chapter 5 of Watts and Charles [53] include: two-storey blocks of eight houses founded on a $12 \mathrm{~m}$ deep (clay) opencast mining backfill at Ilkeston; single-storey factory founded on a $18 \mathrm{~m}$ deep (clay with shale fragments) opencast mining backfill in West Auckland; industrial estate in Brighton founded on a 6-m deep chalk fill suffered $110 \mathrm{~mm}$ settlement; North Tyneside District General Hospital founded on a 20-m deep (clay and shale) opencast mining backfill suffered $160 \mathrm{~mm}$ collapse settlement; Clifford's Tower in York founded on a fill comprising stones, gravel and clay suffered severe cracking; and houses in southern California founded on $30 \mathrm{~m}$ deep engineered sandy clay fill suffered distress from settlement reaching $0.45 \mathrm{~m}$ due to increased wetting. Watts and Charles [53] noted that collapse compression causing these damages occurred several years (5-246) post fill placement while suggesting construction specifications necessary to eliminate collapses in engineered fills as well as treatments for non-engineered fill deposits.

\section{Natural collapsible soils}

Weathering, transportation, and deposition are the natural processes giving rise to soil deposits. With inter-particle bonding present an open structure is produced. Classic collapsible soils are the products of a combination of the preceding processes and particle type and sedimentation mechanisms: resulting in residual, water deposited (quick clay, alluvium), and wind deposited (loess) collapsing soils [48]. They are broadly classified by Fredlund and Gan [24] into wet or dry collapsible soils, with the dry collapsible ones occurring either as cemented or uncemented.

Residual soils are formed in place from decomposition, disintegration and mechanical alteration of parent rock materials [48, 54]. According to Clemence and Finbarr [15], the collapsible structure of residual soils develop from the leaching out and loss of soluble and colloidal materials. Good examples of residual collapsible soils are the granitic sands of South Africa [48] and the decomposed granites in Rhodesia which were found to have a total collapse of about 7 to 10\% (Brink and Kanty, 1961 cited in [4]). 
Water deposited collapsible soils according to Rogers [48] are classified into: the alluvial deposits and quick clays. The alluvial deposits are usually in the form of alluvial fans, floodplains, and mudflows.

Saturated quick clays have been described by Rogers [48] as soils having metastable structure and are unstable under certain conditions. Quick clays have an open structure with short range bonding between particles.

Wind emplaced sediments are the predominant type of collapsible soils, especially loess deposits and to lesser extent loose sand deposits [4, 48]. They are generally unsaturated and are found in arid and semi-arid regions of the world [27, 32]. Collapsible loose sand deposits deposited under desert conditions can be found covering large areas of Southern Africa, and the shifting sand dunes of the Sahara in North Africa. According to Rogers [48] these sands having an open structure are consisted typically of rounded primary mineral particles $(100-200 \mu \mathrm{m})$ supported by short range bonds.

Loess deposits are unsaturated, consisting predominantly of silt-sized particles derived from glacial grinding or cold/hot weathering. Glacial grinding produced loess deposits in the North America. Loess deposits in the Canary Islands, the Cape Verde Islands, and some areas around the Sahara (Northern Nigeria, Libya, and Tunisia) are believed to form from hot weathering processes prevalent in the Sahara $[4,48]$. Rogers [48] also reported the Chinese loess and South American loess from Tibetan Mountain ranges and nearby deserts, and the Andes, respectively as good examples of loess deposits produced from cold weathering. Others are the Bulgarian and Romanian loess from the Danube.

\section{Understanding soil collapse mechanisms}

There is a large body of research aiming to understand the engineering behaviour of both natural and manmade collapsible soils, from a physical (bond alteration) point of view $[21,35,45,49]$ and a mechanical (effective stress) viewpoint $[3,31]$.

Despite the many studies, particularly loess soils dominating the literature, the mechanisms of metastability and consequent $\mathrm{CP}$ are not fully understood [8, 43]. Consequently, several researchers have described collapsible soils in different ways. Some of these definitions can be found in Assallay [4]. Most of them identified collapsible soils as partially saturated, but there seems not to be agreement as to whether collapse occurs only with loading or self-weight. Assallay [4] has made the following conclusions about the general characteristics of collapsible soils:

(1) Collapsible soils have particle sizes ranging from sand, silt, to clay, and angular grains (particularly silts). The size and shape of particles during sedimentation (in the case of natural collapsible soil) or state of compaction (man-made collapsible soil) are responsible for the open structure formed, [48].

(2) They have high void ratio and low density. This was described as open potentially unstable structure, which allows the soil readily undergo particle re-arrangement and volume reduction by self-weight and/loading upon wetting [7]. 
(3) They are highly sensitive. Sensitivity depends on soil mineralogy and type of particle-to-particle bonding agent. For example, quick clays may be more sensitive than sand or silt deposits having calcite as bonding agent.

(4) Collapsible soils are young geological or recently weathered deposits.

(5) Collapsible soils possess relatively low inter-particle bond strength. Collapsing rate was also considered by Barden et al. [7] in terms of bonding strength to be immediate, slower and very slow, depending on whether bonding was by capillary suction (Fig. 2a), clay buttress (Fig. 2b, c), or chemical cementing (iron oxide, calcium carbonate or some other salts), respectively.

(6) They are mostly partially saturated, except for saturated quick clay in which collapse is not triggered by wetting but rather triggered by drying resulting in significant shrinkage [48]. Collapse also occurs when internal forces surpass bond shear strength [33]).

\section{Micromechanics (or bond alteration) point of view}

The influence of internal stress, structural components, and particle arrangements on soil deformation can be described by micromechanics. Discontinuous numerical methods, such as discrete elements are commonly used to formulate relationships in micromechanics.

Mellors [42] studied the influence of clay component on collapse of the soil structure of loess and described the soil grain arrangement and contact modification on the wetting surface of grains under loading. Mellors argued that prior to wetting, and despite the shear stresses due to the external load, inter-particle bonds remained adequately strong to resist shear failure at points of contact. However, upon wetting, microshearing occurred at the point of contact causing collapse of the soil structure. Mellors

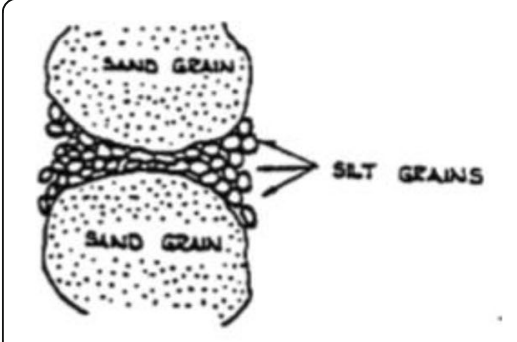

(a) Fine silt bond.

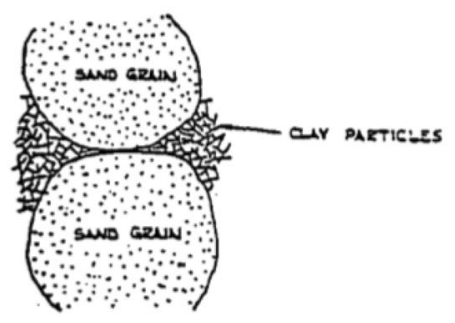

(c) Flocculated clay buttress

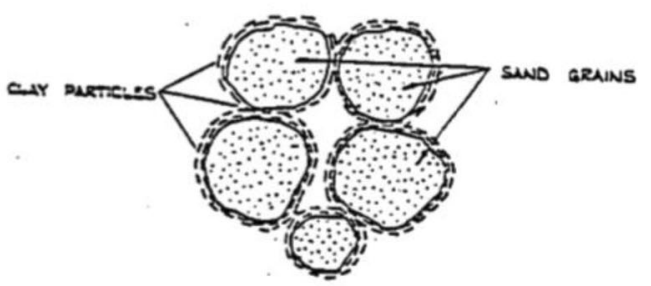

(b) Clay onjon-skin bond.

Fig. 2 Capillary suction bonding and clay bonding in collapsible soils suggested by Barden et al. [7] 
noted that wetting with water reduces the shear strength of the bonds such that it becomes less than the shear stresses acting at the point of contact, thus, collapse occurring. Mellors [42] has used an equation introduced by Lamb, 1960 to explain the mechanism of collapse of the loess. This Eq. (1), which modified the effective stress equation, relates the external stress to the internal stresses in a certain soil system.

$$
\sigma=\sigma^{\prime}+u+R-A
$$

where, $\sigma$ is total external stress, $\sigma^{\prime}$ is effective inter-granular contact stress, $u$ is excess pore pressure, $R=$ inter-particle repulsion per unit area of total inter-particle contact, $A$ is inter-particle attraction per unit area of total inter-particle contact.

On the basis of [42] soil, tested in an air-dry state $(u=0)$ under an external load, Eq. (1) becomes Eq. (2)

$$
\sigma^{\prime}=\sigma-R+A
$$

Following Eq. (2), therefore, wetting leads to the rehydration of clay bonds (or connectors) and the expansion of Diffused Double Layer, reduction in attraction forces $(A)$, increase in repulsion forces $(R)$, and eventual clay bonds' disaggregation. This results in reduced inter-particle shear strength of clayey bonds and consequently shearing occurs at the point of contact [42]. Yun and Santamarina [57] also recognised the impact of bonding on the behaviour of soil, such as small-strain stiffness, resistance to liquefaction and collapse, noting that increasing degree of cementation affects the drained strength of soil (i.e., increasing the small-strain shear modulus, $G_{0}$ ). It is argued that cementation effect depends on the amount and type of cementing material, particle size distribution (the greater the specific surface, the thinner the cement layer around particles), density (inter-granular connection increases with density), and the stresscementation history (i.e. the degree of confinement during cementation) [28]. Experimental [23] and numerical [58] observations reveal debonding and softening occurring during unloading, even in isotropic conditions. That, soils cemented under confinement expand during unloading and the bond at contact point fails in tension. This is an inherent mechanism in sampling [52].

An understanding to the collapse mechanism of soils was provided (Fig. 3) by Feda [22], whose micromechanical view identified "debonding", "grain breakage", "fabric transition (compression, shear)", and "softening-hardening" as four different mechanisms in collapsible soils. Figure 4 also demonstrates the collapse mechanism as described by Rogers [48]. Rogers reported an increase in positive pore water pressure and a decrease in both effective stress and bond shear resistance when wetting takes place. Decrease in bond shear resistance can better explain the collapse phenomenon as increase in positive pore water pressure, according to classic soil mechanics, should lead to increase in volume (heave) rather than collapse.

\section{The mechanical or effective stress viewpoint}

The effective stress concept (Terzaghi, 1963 in Skempton [50]) is well-established in the mechanics of saturated soils. Terzaghi developed the concept for a single dominant porosity transmitting single fluid, but later, Bishop [10] and Matyas and Radhakrishna [40] developed different forms for pores transmitting two immiscible and miscible fluids, respectively. Efforts have been made by many researchers (e.g. [10, 25, 31]) to 


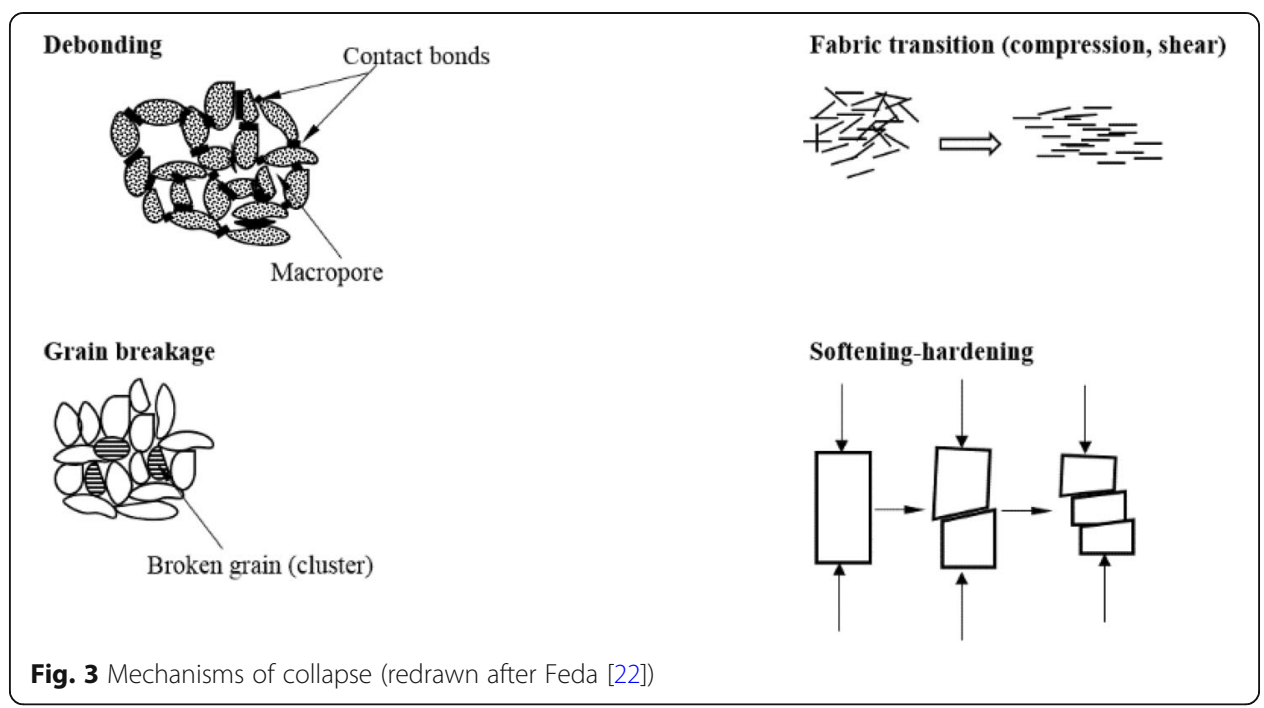

extent the effective stress concept to cover unsaturated soils based on three types of stress variable; attempts to combine pore air pressure, pore water pressure, and total stress within a single effective stress variable. A notable Eq. (3) based on two stress states (net stress and matric suction) (Fig. 5) and a soil parameter $(\chi)$ was proposed by Bishop [10].

$$
\sigma^{\prime}=\left(\sigma-u_{a}\right)+\chi\left(u_{a}-u_{w}\right)
$$

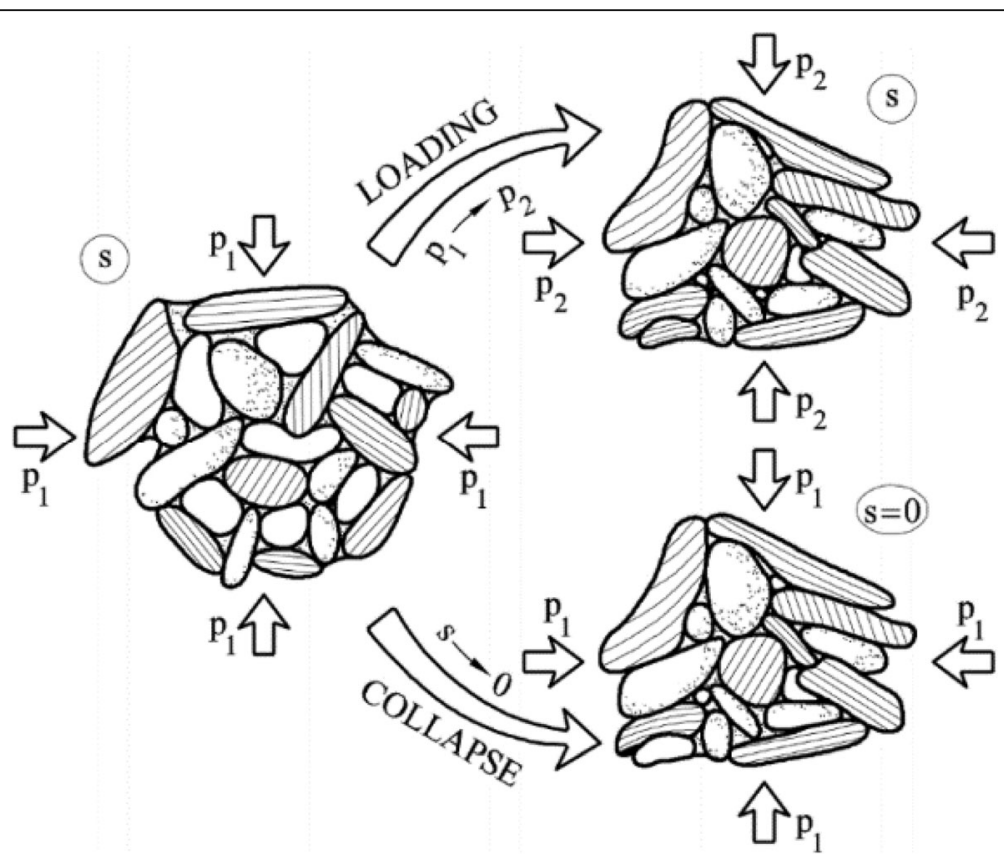

Fig. 4 Collapse caused by wetting or stressing (after Rogers [48]) 


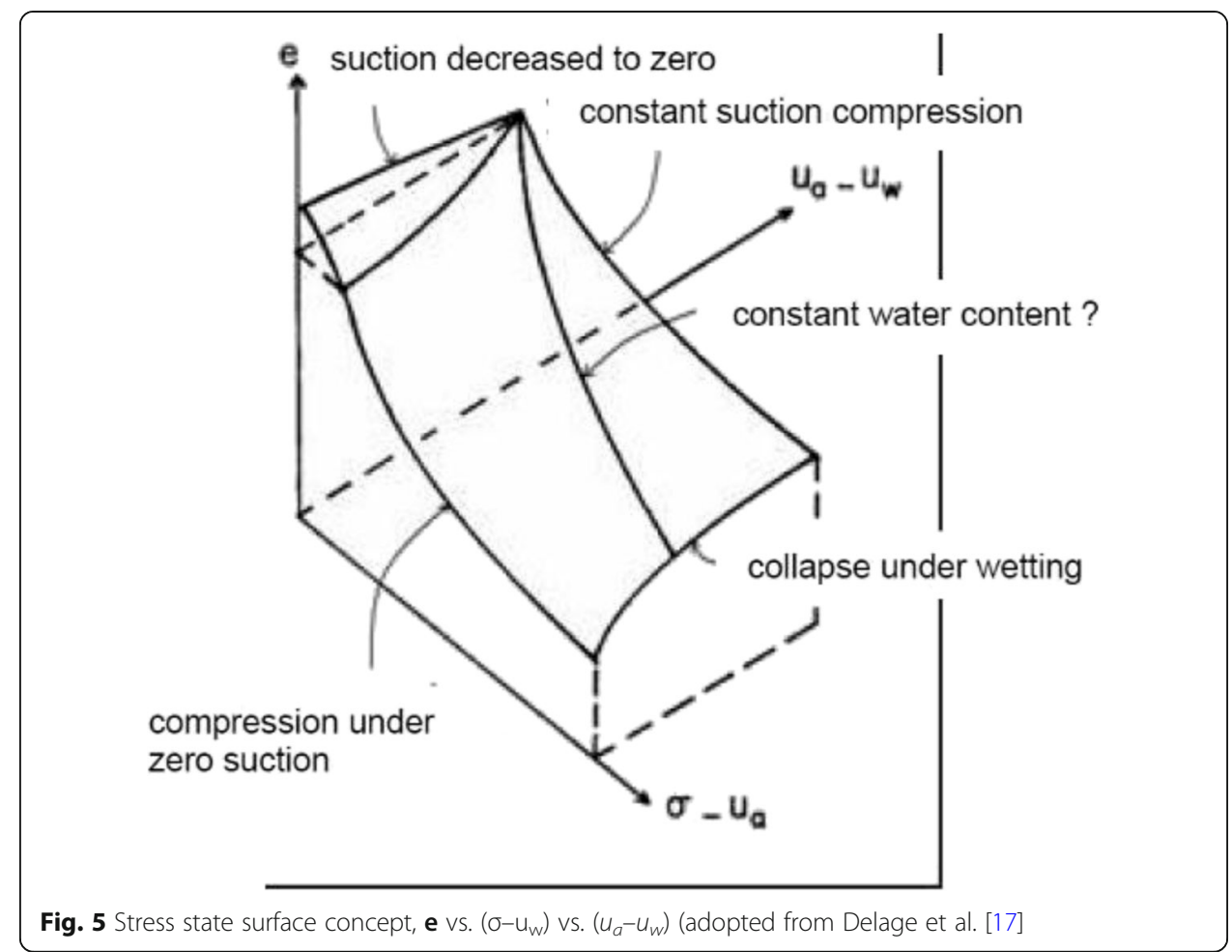

where $\sigma^{\prime}$ is effective stress, $\sigma$ is total stress, $u_{a}$ is pore air pressure, $u_{w}$ is pore water pressure, and $X=$ a soil parameter (a function of degree of saturation, $S_{r}$ varying from 0 to $100 \%)$.

Collapsible soils are characteristically unsaturated with significant collapse usually occurring prior to reaching a fully saturated state (Markin 1969, in [4, 16, 27]). Therefore, several authors $[24,25]$ have used the concepts of unsaturated soils mechanics for describing the collapse mechanism. Extending the two stress state variables method by Bishop [10] to study volume change behaviour resulting from loading and wetting of collapsible soils, Fredlund and Gan [24] described collapse to occur from the loss of strength as suction decreases with wetting. Following this, suction-controlled wetting tests have been largely adopted to study the behaviour of collapse, and with relation to Eq. (3), several commonly used constitutive models where suggested for modelling the collapse behaviour with respect to varying matric suction as a stress state variable (Fredlund and Gan [24]; Wheeler et al. [55]). Other not commonly used equations have also been developed for soils idealised as 4-phasic materials (with or without phase interfaces) $[17,25]$.

However, earlier studies, e.g. Jennings and Burland [31] claim that Bishop's Eq. (3) was not capable of adequately relating volume change with effective stress in an unsaturated collapsible soil; since a decrease in suction reduces the effective stress and increases the volume (see Fig. 6).

A large body of research carried out to develop a suitable function for the soil parameter, $X$ in the Eq. (3), with $X$ equated to saturation ratio [11], but Alonso et al. [3] argue that this choice is for soils containing clay, with the residual saturation ratio greater than zero, thus $\chi\left(u_{a}-u_{w}\right) \rightarrow \infty$ when $\left(u_{a}-u_{w}\right) \rightarrow \infty$. 


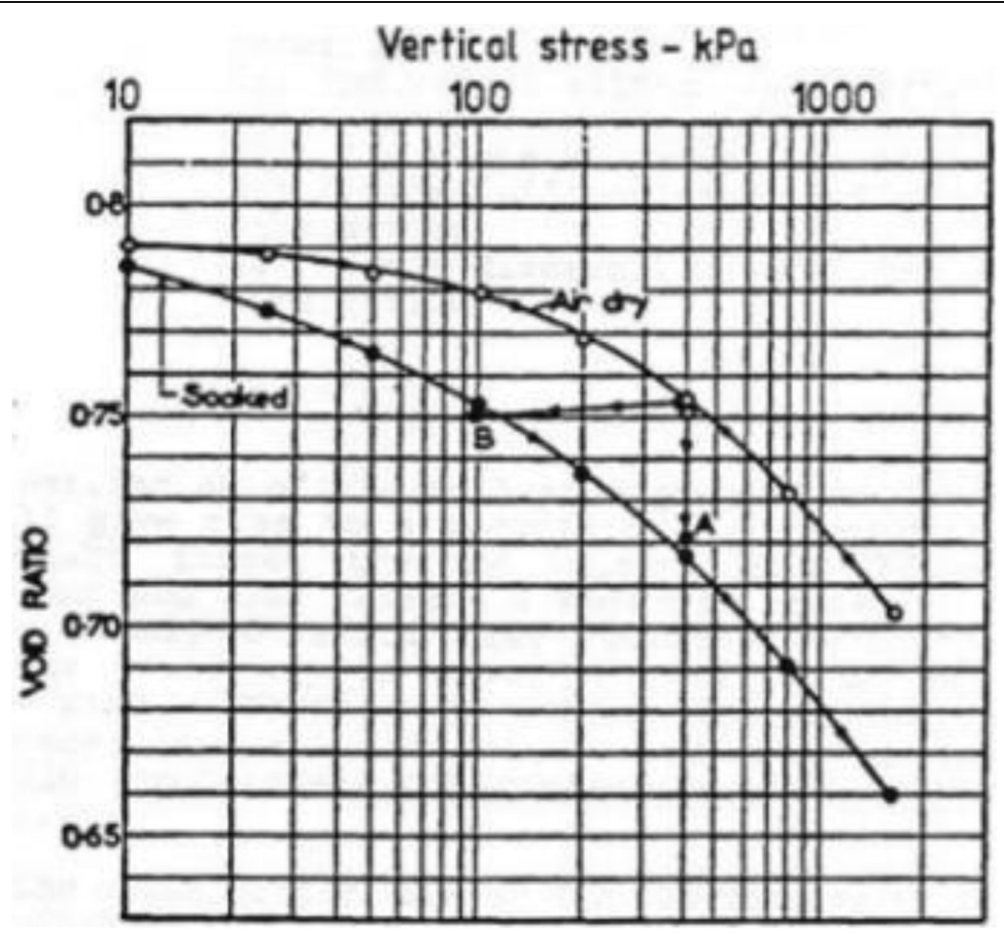

Fig. 6 Oedometer compression on air-dry and saturated silt showing the effect of soaking [13]

Considering the influence of suction on inter-particle forces, Burland and Ridley [14] used the grain column analogy (Fig. 7) to explain the difficulties posed by the single effective stress in describing unsaturated soil behaviour. They noted that, the impact of a suction acting through the menisci at grains contact points is to provide a stabilising effect, while the influence of a boundary stress is to cause grain slip. The two stress systems give rise to completely different mechanical effects and therefore should not be considered together.

\section{Predicting collapse in soils}

Sensitivity of a soil in terms of the rate and magnitude of collapse must be predictable if a geotechnical engineer is to prevent possible damage to infrastructure built with or hosted on potentially collapsible soils. Several methods of predicting and categorising collapse in soils have been reported by many authors. These are relationships of fundamental properties, field tests, and qualitative/quantitative experimental methods.

\section{Relationship of fundamental properties}

Collapse has been predicted by indirectly relating parameters like clay content, void ratio, degree of saturation, Atterberg Limits, moisture content, and density.

Data from an extensive literature review on the impact of clay content on the collapsibility of loessial soils [4] has been used to create plots [33] to delineate boundaries where clay content influences collapsibility differently under wetted conditions. Langroudi [33] present 5 to $40 \%$ kaolinite clay contents as indicative of possible collapse 


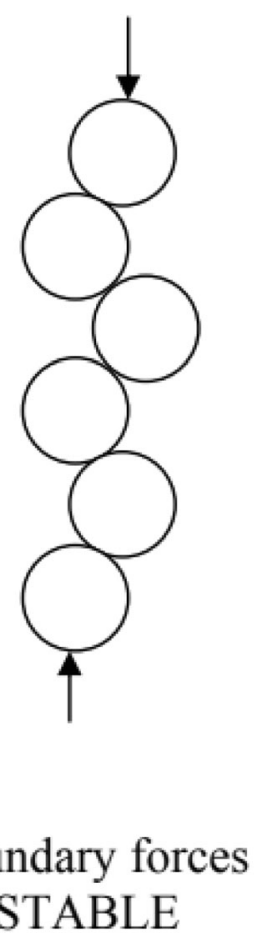

Boundary forces

UNSTABLE

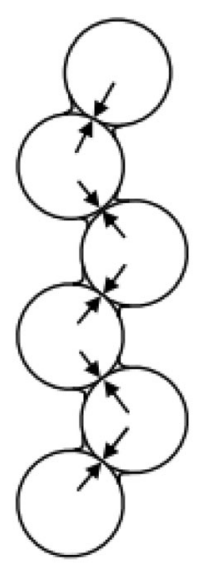

Contact menisci STABLE

Fig. 7 Grain column analogy [14]

but most vulnerable between 11 and $24 \%$ with the highest chance of collapse occurring between 8 and 15\% regardless of packing state.

Earlier in 1973, Handy (Bell and Culshaw [9]; Bell et al. [8]) suggested higher collapses with reducing clay content. However, Handy only cited a high probability of collapse for samples having less than $16 \%$ clay content, which agrees with Langroudi [33]. Nevertheless, Handy claims that no collapse should be expected in soils with more than $32 \%$ clay content, contradicting the position of Langroudi. El Sohby and Rabbaa (1984)'s data of collapse test of two mixes (sand-clay and silt-clay) as reported by Lawton et al. [35] (Fig. 8) recorded maximum collapses at clay contents of about 30-40\% and $10-20 \%$, respectively. Beyond those ranges swelling occurred. Another soil (Ottawa sand-Kaolin mix) studied by Lawton revealed maximum collapse occurring between 12 and $16 \%$ clay content (Fig. 8). It is obvious that defining collapse solely on clay content can be misleading, as other factors such as type of clay, dry density, bonding strength, wetting fluid type, etc. can all affect collapse as demonstrated by some experimental results (Fig. 9) of the current study.

The views discussed in Assallay [4] tended to relate purely non-active clays to the collapse structure whereas Langroudi [33] citing Russell 1944, Handy 1973, Lattman 1973 and Parsons et al. 2009, reported active clay minerals as also contributing to collapse, with special mention of the collapsible loessial deposits in the central areas of North America. Feda [21] also considered collapse occurring with active clays, but at water contents lower than a certain threshold and overburden stresses higher than their swelling pressures. The collapsible Tucson alluvial clay (majorly montmorillonite) [7] is a good example. 


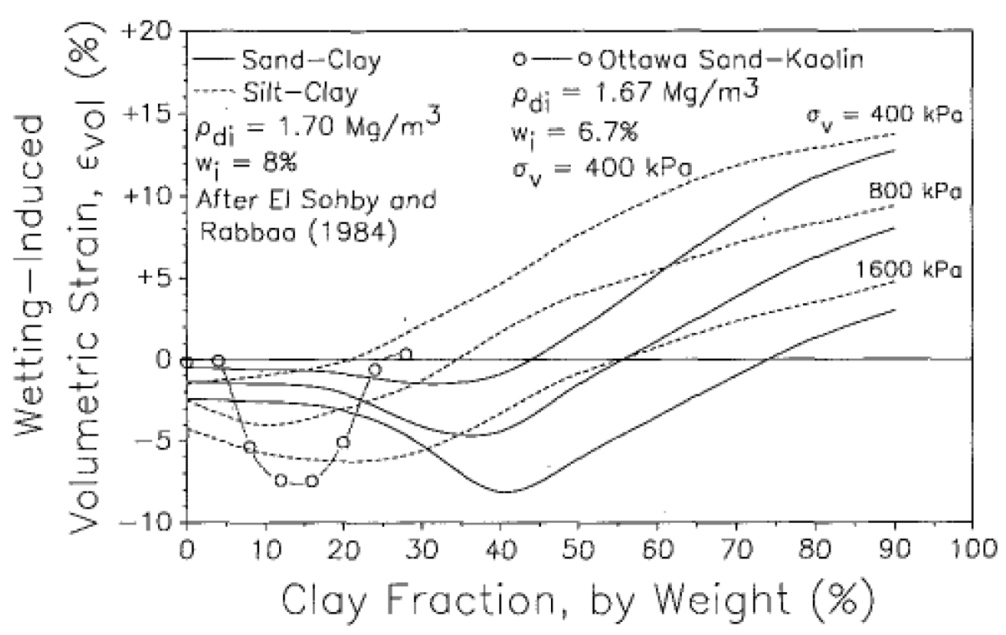

Fig. 8 Effect of clay content on collapse potential (adopted from Lawton [35])

Denisov understood the control of porosity in metastable soils, and in 1951 proposed the void ratio relationship $[2,4,16]$ at natural moisture content and at liquid limit, to predict collapse as in Eq. (4). Assallay [4] quoted Skempton and Northey, 1953 reporting the validity of this equation in also predicting collapse in saturated quick clay as its Liquid Limit usually falls below the natural water content.

$$
K=\frac{e_{L}}{e_{0}}
$$

where $K$ is coefficient of subsidence, $e_{L}$ is void ratio at the Liquid Limit, $e_{0}$ is natural void ratio. $K=0.5-0.75$ for highly collapsing soils, $K=1.0$ for non-collapsible loam, $K$ $=1.5-2.0$ for non-collapsible soils.

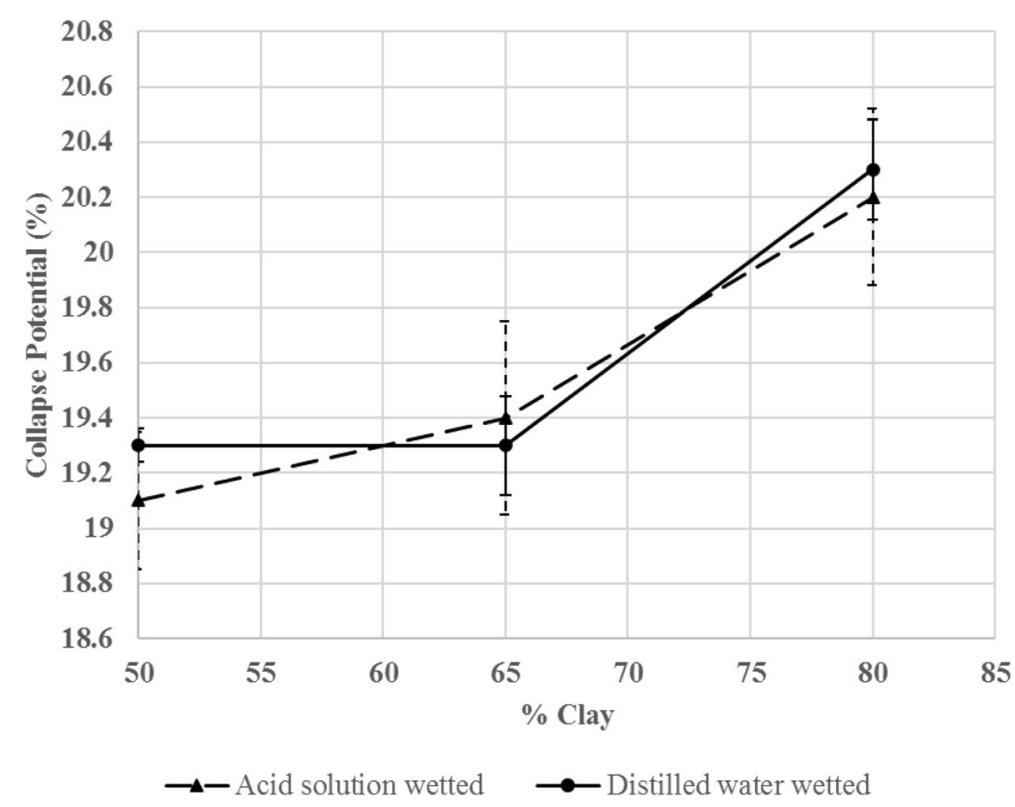

Fig. 9 Effect of clay content on the CP of silty-clay soils with different wetting fluids 
The natural degree of saturation $\left(S_{\mathrm{o}}\right)$ was used to predict collapse according to the new Soviet Building Code (Darwell et al. [16]; Markin 1969, in Assallay [4]). If $\mathrm{S}_{\mathrm{o}}$ is not more than 0.6 and Eq. (5) yields $L>-0.1$ then soil is collapsible. The equation can also reveal swelling potential if the equation yields $L$ less than - 0.3 (Danilov 1964, in Assallay [4]).

$$
L=\frac{e_{0}-e_{L}}{1+e_{0}}
$$

Based on moisture content and Atterberg limits relationship the following equations were proposed. Equation 6 by Denisov 1951 and modified by Priklonskij 1952; Eq. (7) by Gibbs and Bara 1962; Eq. (8) by Feda 1964 (Alan and Robert [2]; Assallay [4]).

$$
K=\frac{w_{0-P L}}{P I}=\frac{w_{0-P L}}{L L-P L}
$$

where $\mathrm{K}$ is collapsibility index, $w_{o}$ is natural water content, $P L$ is plastic limit, $L L$ is liquid limit, $P I$ is plasticity index, and Priklonskij proposed the following $K$ limits collapse categories:

$K<0$ for highly collapsible soils, $K>0.5$ for non-collapsing soils

$K>1.0$ for swelling soils

$$
L I=\frac{w_{0}-P L}{L L-P L}
$$

when LI approaches or exceeds a value of unity, collapse may occur

$$
K=\left(\frac{w_{o}}{S_{0}}\right)-\left(\frac{P L}{P I}\right)
$$

where $S_{\mathrm{o}}$ is natural degree of saturation.

In 1964, Feda stated that collapse is probable when $K<0.85$, and then in 1966 he employed initial porosity, $n_{o}$ to classify collapse reporting soils with $n_{o}$ greater than 0.4 as susceptible to collapse [2].

Based on density and Atterberg limits relationships, the following equations where proposed: Eq. (9) by Gibbs and Bara 1962 (Assallay [4]).

$$
R=\frac{W_{s}}{W_{L}}=\frac{\left[\left(\frac{\rho_{w}}{\rho_{d}}\right)-\left(\frac{1}{G_{S}}\right)\right]}{W_{L}}
$$

where $R$ is collapse ratio, $W_{s}$ is water content at $100 \%$ degree of saturation, $W_{L}$ is water content at liquid limit, $\rho_{w}$ is density of water, $\rho_{d}$ is dry density of soil, $G_{s}$ is specific gravity of solid particles.

Collapse of soil is imminent on saturation when $R$ is greater than or equal to unity. A graphical criterion (Fig. 10) to predict soil collapse was created based on Eq. (9)

Soil dry density has also been used solely to categorise CP. Dry densities less than $1.28 \mathrm{Mg} / \mathrm{m}^{3}$ indicate large settlements to be expected while greater than $1.44 \mathrm{Mg} / \mathrm{m}^{3}$ indicate small settlements to be expected (Clevenger 1958 in Alan and Robert [2]).

\section{Field predicting methods}

Two field collapse-predicting methods were proposed in 1957 by Jennings and Knight: the "sausage" test and "cylinder" test [4]. The sausage test involves taking a handful 


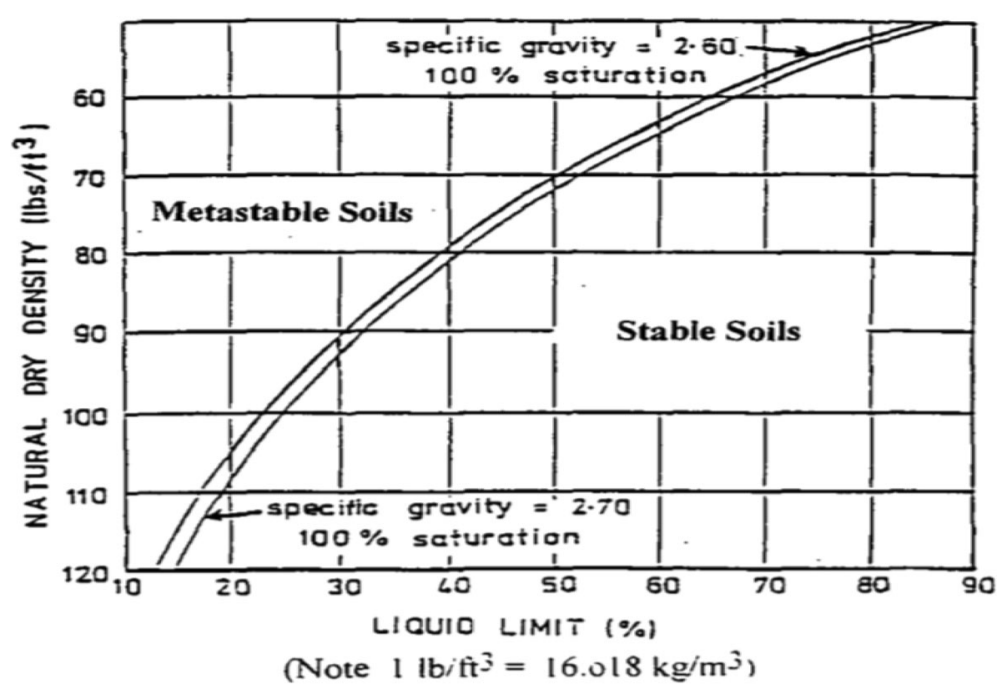

Fig. 10 Stable and metastable (collapsible) soil (after Gibbs and Bara 1962) [4]

sample from the site and dividing it into two equal parts. One part is wetted and moulded into a ball while the other left dry unmoulded. The volumes of the two are then compared. Collapse is said to be imminent if the volume of the wet ball is less than that of the dry unmoulded part. Accuracy of this test was checked by wetting and moulding the second part, also into a ball to compare the volumes of the two balls. If the same, then the procedures were accurate.

The cylinder test involved sampling a $100 \mathrm{~mm} \times 50 \mathrm{~mm}$ undisturbed sample and dividing it into two equal parts of $50 \mathrm{~mm} \times 50 \mathrm{~mm}$ each. One part is wetted and remoulded by hand into the $50 \mathrm{~mm} \times 50 \mathrm{~mm}$ cylinder while the other remained undisturbed. Collapse was said to be imminent if the height of the wetted remoulded specimen falls below that of the undisturbed [4]. These field methods are only qualitative, and do not consider the fact that some bonding agents such as calcite (in some calcareous soils) may not be readily soluble, and collapse may not be predictable with these methods.

There are several field instrumentation methods used to assess collapse. They are generally grouped into in-situ tests such as field vane, standard penetration test (SPT), cone penetration test $(\mathrm{CPT})$, dynamic probing (DP), flat dilatometer (DMT), pressure meter (PMT) including the Menard pressure meter (MPM) and the self-boring pressure meter (SBP); load tests; and geophysical tests [53]. However, the commonly used ones are pressure meter tests, plate loading tests, and geophysical tests [20], with each presenting their unique disadvantages. The major disadvantage of in situ methods is the ground disturbance and point specific nature of assessment [20]. One vital aspect with any field assessment is the number of tests necessary to satisfactorily characterise the CP [30]. Statistical approaches developed to evaluate the minimum number of tests necessary to adequately characterise a site and its CP, have been discussed by Houston et al. [27].

Geophysical methods such as ground-probing radar and electrical resistivity are occasionally used but, in many circumstances, seismic methods are the most suitable geophysical techniques [53]. Notwithstanding, Evans et al. (2004) have demonstrated the 
usefulness of electrical resistivity (resistivity/moisture content imaging techniques) in measuring moisture content variation in a red clay embankment located in Kenya, and to monitor water movements during a field "hydo-collapse" trial of loess material in Kent. Stiffness changes in the Kent loess material caused by wetting under an applied load were also monitored by shear-wave transducers installed at depth intervals, to complement the resistivity/moisture imaging [20]. Additionally, critical properties of collapsible soils such as density and porosity are indirectly obtainable from borehole geophysical logging techniques like resistivity, acoustic, nuclear, and self-potential logs [41]. Wyllie et al. [56] proposed an empirical Eq. (10), which has been used for many years to estimate porosity of saturated soil deposits from sonic logs. Recently, Abatan et al. [1] related acoustic data with estimated porosity data revealing great influence of porosity on P-wave velocity $\left(V_{P}\right)$ and S-wave velocity $\left(\mathrm{V}_{\mathrm{S}}\right)$ with both decreasing with increasing porosity.

$$
\frac{1}{V_{P}}=\frac{n}{V_{f}}+\frac{(1+n)}{V_{m}}
$$

where, $n=$ fractional porosity, $V_{P}=P$-wave velocity, $V_{f}=$ velocity through the pore fluid, and $V_{m}=$ velocity through the matrix.

\section{Laboratory predicting methods}

Houston et al. [27] and Jefferson et al. [30] suggest that the most effective way to assess collapsibility of a soil is by laboratory testing. Assallay [4] also note that empirical methods (relationship of properties) are less reliable compared to laboratory approaches, owing that the latter takes soil structure pattern into consideration. Laboratory methods give both qualitative and quantitative results in that amounts of collapse can also be predicted. Two laboratory methods typical are standard oedometer and triaxial methods. Both take into consideration key conditions such as the dry density, the initial water content, and the applied load, which control densification of most soils under wetting. Both methods also have provision for inundation. However, Houston et al. [27] argue that traditional oedometer tests suffer from effects of specimen disturbance and most times reach saturations not normally encountered in the field. Jefferson et al. [30], therefore, recommend that traditional oedometer tests should at best be considered index tests and a field trial should be conducted for full collapse assessment.

In the triaxial test, inundation is through the lower end of the specimen, while it is complete submersion of specimen in the oedometer [4,37]. Normal laboratory procedures are employed: soaked-after-loading is employed in one-dimensional oedometer test and three-dimensional triaxial tests, where specimen is loaded incrementally until equilibrium is reached and then inundated. This is referred to in the oedometer testing method as "single oedometer". A second procedure involving wetting at loading time (referred to as "double oedometer") has also been adopted in the oedometer method. Figure 11 demonstrates these procedures in predicting collapse. Details of the experimental procedures and other recommendations can be found in Assallay [4] and Standards for soil testing.

Incremental vertical stress before inundation up to $300 \mathrm{kN} / \mathrm{m}^{2}$ in one-dimensional single oedometer compression test has been recommended as most meaningful to geotechnical engineers for predicting collapse in soils (Abelev 1948 in Alan and Robert [2]; 


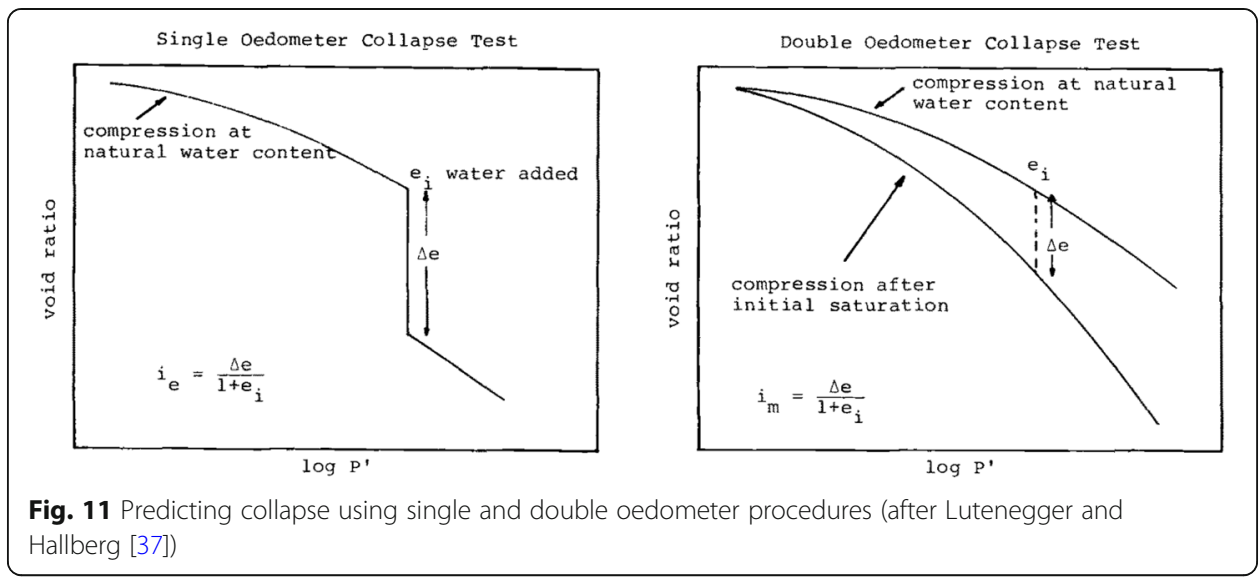

Lutenegger and Hallberg [37]). Their methods involved applying approximately 300 $\mathrm{kN} / \mathrm{m}^{2}$ vertical stress at natural moisture content and then inundating the specimen. Lutenegger and Hallberg [37] have reported collapse as imminent if volume decreases at constant load, and that the coefficient of collapse, $i$, determined by Eq. (11) yielding values greater than $0.02(2 \%)$ as indicative of danger with respect to the United States perspective of collapse. However, different regions have adopted different values to delineate collapsible soils. For instance, in Chinese context soils with CP equal to or greater than $1.5 \%$ are considered collapsible [19] while in the British viewpoint, soils exhibiting CP greater than $1 \%$ are regarded as collapsible or metastable soils [9].

$$
i=\frac{\Delta e}{1+e_{i}}
$$

where $\Delta e=$ change in void ratio upon wetting, $e_{i}=$ void ratio at beginning of wetting Knight 1963 and Jenning and Knight 1975 (cited in Alan and Robert [2]; Mohamed et al. [44]) have rather recommended triggering collapse by wetting at $200 \mathrm{kPa}$ incremental stress, and defining CP as in Eq. (12). However, several workers around the globe have adopted various wetting vertical stresses, in the range of 50 to $600 \mathrm{kN} / \mathrm{m}^{2}$.

Therefore, rather than a recommended stress, a stress level close to estimated foundation stresses for proposed projects should be preferred for collapse testing [2]. Again, from these two experimental definitions of CP (Eqs. 11 and 12), choice of initial void ratio is a contradictory one. While Eq. (11) uses void ratio immediately before wetting, Eq. (12) preferred natural void ratio. This is capable of producing inconsistent results, especially if compression before wetting is large and Eq. (11) has not taken this into consideration and Eq. (12) would overestimate collapse as it considers pre-wetting compression as collapse.

$$
i_{c}=\frac{\Delta e_{c}}{1+e_{o}}
$$

where $\Delta e_{c}=$ change in void ratio due to wetting, $e_{o}=$ natural void ratio

Furthermore, since the oedometer test is performed as a one-dimensional test, collapse can also be defined in terms of percentage change in specimen height as in Eq. (13) [5]. 


$$
i_{c}=\frac{\Delta h}{h_{o}} \times 100
$$

where $\Delta h=$ change in specimen height due to wetting, $h_{0}=$ specimen height before wetting.

Ayadat and Hanna [6] made an extensive comparison of the different collapse predicting methods available in the literature. They used various soils of different depositional histories and some of the soils adopted to model certain of the predicting methods to evaluate other proposed methods. They found many comparative contradictions between most of the proposed methods and concluded on a generally note that nearly no one criterion would predict the collapsibility of any soil accurately. Delage et al. [17] also compared some of the proposed indirect methods with results of experiments they carried out and found many of them incomparable. Thus, a combination of several techniques is necessary to effectively predict collapse (Jefferson et al. [30]; Watts and Charles [53]).

\section{Conclusions}

- There is some consensus on what features make a soil metastable or collapsible whether natural or anthropogenic. Foremost of these features include an open structure, unsaturated state, low dry density, high void ratio and porosity, and high enough initial bonding.

- Almost all kinds of soils can exhibit collapse features given the right conditions of placement or ageing, but loess or loessial soils appear to be the commonest forms of collapsible soils dominating the literature.

- Several techniques for predicting and classifying collapse have been proposed. They are grouped into indirect correlations, laboratory, geophysical, and field loading methods. Although laboratory methods are seen to be best for describing these soils, it is argued that no single testing method is adequate to fully describe collapse in any soil. Nevertheless, collapse testing should be site specific and anticipatory.

- The open structure of collapsible soils is argued to form from the support of bonding existing at particle contacts, which provides an initial high strength and stiffness. Either or a combination of, suction, clay, calcium carbonate, or other salts provide this bonding. Fundamentally, collapse is said to occur where the bonding element at the particle contacts is weakened or destroyed upon wetting with or without stressing.

Abbreviations

ASTM: American Standards for Testing Materials; BRE: Building research establishment; BS: British standard; CP: Collapse potential; CPT: Cone penetration test; DMT: Flat dilatometer; DP: Dynamic probe; MPM: Menard pressure meter; PMT: Pressure meter; SBP: Self-boring pressure meter; SPT: Standard penetration test; UK: United Kingdom; US\$: United States dollar; $V_{p}$ : P-wave velocity; $V_{S}$ : S-wave velocity

\section{Supplementary Information}

The online version contains supplementary material available at https://doi.org/10.1186/s44147-021-00064-2.

Additional file 1 Table S1 Some examples of structural instability caused by collapsible soils. Figure S12 Microstructure model of a collapsible loess deposit as suggested by Tan 1988 (after Assallay (1998)). Figure S13 Clean edge-to-edge fabric in angular coarse silt Malan loess (Derbyshire and Mellors, 1988). Table S2 Classification of loess bonding types by Yang 1989 (adapted from El Howayek et al. (2011)). Table S3 classification of structural 
bonds in loess (adapted from Osipov and Sokolov (1995). Figure S14 Structural bonds transformation in loess under water saturation (redrawn after Osipov and Sokolov (1995)). Table S4 Comparison of collapse sequences according to Osipov and Sokolov (1995), and Klukanova and Frankovska (1995).

\section{Acknowledgements}

The authors wish to acknowledge the Petroleum Technology Development Fund (PTDF) Nigeria for their financial sponsorship of the first author, to carry out this study as part of a PhD programme at the Newcastle University, UK.

\section{Authors' contributions}

This article is part of the PhD work of the first author (Opukumo, Alfred Wilson). The PhD work was jointly supervised by the second (Davie, C. T.) and third (Glendinning, S.) authors at the School of Engineering, Newcastle University, UK. The fourth author (Oborie, E.) contributed to the modification of the thesis material into this article. All authors have read and approved the manuscript.

\section{Authors' information}

OAW (PhD Geotechnical Engineering)—Lecturer at the Department of Geology Niger Delta University, Wilberforce Island, Bayelsa State, Nigeria. DCT (PhD Geotechnical Engineering)—Reader at the School of Engineering, Newcastle University, Newcastle upon Tyne, UK. GS (PhD Geotechnical Engineering)—Professor of Civil Engineering at the School of Engineering, Newcastle University, Newcastle upon Tyne, UK. OE (PhD Hydrogeology/Geophysics)—Senior lecturer at the Department of Geology Niger Delta University, Wilberforce Island, Bayelsa State, Nigeria.

\section{Funding}

This work was part of a PhD thesis funded by the Petroleum Technology Development Fund, Nigeria.

\section{Availability of data and materials}

All data generated or analysed during this study are included in this article.

\section{Declarations}

\section{Competing interests}

The authors declare that they have no competing interests.

\section{Author details}

${ }^{1}$ Department of Geology, Niger Delta University, Wilberforce Island, Amassama, Bayelsa State, Nigeria. ${ }^{2}$ School of Engineering, Newcastle University, Newcastle upon Tyne, UK.

Received: 15 September 2021 Accepted: 19 December 2021

Published online: 05 February 2022

\section{References}

1. Abatan AO, Akinyemi OD, Olowofela JA, Ajiboye GA, Salako FK (2016) Experimental investigation of factors affecting compressional and shear wave velocities in shale and limestone of Ewekoro formation of Southern Nigeria sedimentary basin. Environ Earth Sci 75(22):1442

2. Alan JL, Robert TS (1988) Determination of collapse potential of soils. Geotech Test J 11(3):173-178

3. Alonso EE, Pereira JM, Vaunat J, Olivella S (2010) A microstructurally based effective stress for unsaturated soils. Géotechnique 60(12):913-925. https://doi.org/10.1680/geot.8.P.002

4. Assallay AM (1998) Structure and hydrocollapse behaviour of loess. Loughborough University, Doctoral dissertation

5. ASTM (D 5333-03) Standard test method for measurement of collapse potential of soils. Annual book of ASTM standards. 2003:4

6. Ayadat T, Hanna AM (2012) Assessement of soil collapse prediction methods. Int J Eng 25(1):19-26

7. Barden L, McGown A, Collins K (1973) The collapse mechanism in partly saturated soil. Eng Geol 7(1):49-60. https://doi. org/10.1016/0013-7952(73)90006-9

8. Bell F, Culshaw M, Northmore K (2003) The metastability of some gull-fill materials from Allington, Kent, UK. Q J Eng Geol Hydrogeol 36(3):217-229. https://doi.org/10.1144/1470-9236/02-005

9. Bell FG, Culshaw MG (2001) Problem soils: a review from a British perspective. In: Jefferson I, Murray EJ, Farangher E, Fleming PR (eds) Problematic soils. Thomas Telford, Nottingham

10. Bishop AW (1959) The principle of effective stress. Teknisk ukeblad 39:859-863

11. Borja Rl, Koliji A (2009) On the effective stress in unsaturated porous continua with double porosity. J Mech Phys Solids 57(8):1182-1193. https://doi.org/10.1016/j.jmps.2009.04.014

12. Briscolland R, Chown R (2001) Problem soils: a review from a British perspective. In: Proceeding of Problematic Soils Conference, Nottingham, pp 53-66

13. Burland J (1965) Some aspects of the mechanical behaviour of party saturated soils. Moisture Equilib Moisture Changes Soils Beneath Covered Areas, pp 270-278

14. Burland J, Ridley A (1996) The importance of suction in soil mechanics. In: Proceedings of the 12th South-East Asian Conference on Unsaturated Soils, Kuala Lumpur vol 2, pp 27-49

15. Clemence SP, Finbarr AO (1981) Design considerations for collapsible soils. J Geotech Geoenviron Eng 107(3):305-317

16. Darwell JL, Denness B, Conway BW (1976) Prediction of metastable soil collapse. In: Proceedings of the Anaheim Symposium of the International Association of Hydrological Sciences, $\mathrm{P} 121$

17. Delage P, Cui Y-J, Antoine P (2008) Geotechnical problems related with loess deposits in Northern France. arXiv preprint arXiv:0803.1435 
18. Derbyshire E (2001) Geological hazards in loess terrain, with particular reference to the loess regions of China. Earth Sci Rev 54(1):231-260. https://doi.org/10.1016/S0012-8252(01)00050-2

19. Derbyshire E, Meng X, Wang J, Zhou Z, Li B (1995) Collapsible loess on the loess plateau of China. In: Genesis and properties of collapsible soils. Springer, Dordrecht, pp 267-293

20. Evans RD, Jefferson I, Northmore KJ, Jackson P (2004) In-situ investigation of problematical soils. In: Advances in geotechnical engineering: The Skempton conference: Proceedings of a three day conference on advances in geotechnical engineering, organised by the Institution of Civil Engineers and held at the Royal Geographical Society London, UK, on 29-31 March 2004 (1269-1279). Thomas Telford Publishing

21. Feda J (1988) Collapse of loess upon wetting. Eng Geol 25(2-4):263-269. https://doi.org/10.1016/0013-7952(88)90031-2

22. Feda J (1995) Mechanisms of collapse of soil structure. In: Genesis and Properties of Collapsible Soils, pp 149-172

23. Fernandez A, Santamarina J (2001) Effect of cementation on the small-strain parameters of sands. Can Geotech J 38(1): 191-199. https://doi.org/10.1139/t00-081

24. Fredlund DG, Gan JKM (1995) The collapse mechanism of a soil subjected to one-dimensional loading and wetting. NATO ASI Ser C Math Phys Sci Adv Study Inst 468:173-206

25. Fredlund DG, Rahardjo H (1993) Soil mechanics for unsaturated soils. Wiley. https://doi.org/10.1002/9780470172759

26. Hosseini A, Haeri SM, Mahvelati S, Fathi A (2019) Feasibility of using electrokinetics and nanomaterials to stabilize and improve collapsible soils. J Rock Mech Geotech Eng 11(5):1055-1065. https://doi.org/10.1016/j.jrmge.2019.06.004

27. Houston S, Houston W, Zapata C, Lawrence C (2001) Geotechnical engineering practice for collapsible soils. Geotech Geol Eng 19(3-4):333-355. https://doi.org/10.1023/A:1013178226615

28. Jarrard RD, Niessen F, Brink JD, Bücker C (2000) Effects of cementation on velocities of siliciclastic sediments. Geophys Res Lett 27(5):593-596. https://doi.org/10.1029/1999GL008429

29. Jefferson I, Rogers C (2012) Collapsible soils. In: Proceedings of ICE Manual of Geotechnical Engineering. ICE Publishing London, pp 391-411

30. Jefferson I, Rogers C, Evstatiev D, Karastanev D (2005) Treatment of metastable loess soils: lessons from Eastern Europe. In: Elsevier geo-engineering book series, vol 3, pp 723-762. https://doi.org/10.1016/S1571-9960(05)80028-X

31. Jennings JEB, Burland JB (1962) Limitations to the use of effective stresses in partly saturated soils. Géotechnique 12(2): 125-144. https://doi.org/10.1680/geot.1962.12.2.125

32. Johari A, Golkarfard H, Davoudi F, Fazeli A (2021) Experimental investigation of collapsible soils treatment using nanosilica in the Sivand Dam Region, Iran. Iran J Sci Technol Trans Civil Eng:1-10

33. Langroudi AA (2014) Micromechanics of collapse in loess. (Doctoral dissertation, University of Birmingham)

34. Lawton EC, Fragaszy RJ, Hardcastle JH (1989) Collapse of compacted clayey sand. J Geotechn Eng 115(9):1252-1267. https://doi.org/10.1061/(ASCE)0733-9410(1989)115:9(1252)

35. Lawton EC, Fragaszy RJ, Hetherington MD (1992) Review of wetting-induced collapse in compacted soil. J Geotech Eng 118(9):1376-1394. https://doi.org/10.1061/(ASCE)0733-9410(1992)118:9(1376)

36. Li P, Vanapalli S, Li T (2016) Review of collapse triggering mechanism of collapsible soils due to wetting. J Rock Mech Geotech Eng 8(2):256-274. https://doi.org/10.1016/j.jrmge.2015.12.002

37. Lutenegger AJ, Hallberg GR (1988) Stability of loess. Eng Geol 25(2):247-261. https://doi.org/10.1016/0013-7952(88)9003 0-0

38. Mahmood MS, Abrahim MJ (2021) A review of collapsible soils behavior and prediction. In: IOP Conference Series: Materials Science and Engineering, vol 1094, No. 1. IOP Publishing, p 012044

39. Mansour ZM, Chik Z, Taha MR (2008) On the procedures of soil collapse potential evaluation. J Appl Sci 8(23):44344439. https://doi.org/10.3923/jas.2008.4434.4439

40. Matyas EL, Radhakrishna H (1968) Volume change characteristics of partially saturated soils. Géotechnique 18(4):432-448 https://doi.org/10.1680/geot.1968.18.4.432

41. McDowell P, Barker RD, Butcher A, Culshaw M, Jackson P, McCann D, Skipp B, Matthews S, Arthur J (2002) Geophysics in engineering investigations. Ciria London, UK

42. Mellors TW (1995) The influence of the clay component in loess on collapse of the soil structure. In: Genesis and properties of collapsible soils. Springer, Dordrecht, pp 207-216

43. Milodowski AE, Northmore KJ, Kemp SJ, Entwisle DC, Gunn DA, Jackson PD, Boardman DI, Zoumpakis A, Rogers CDF, Dixon N (2015) The mineralogy and fabric of 'Brickearths' in Kent, UK and their relationship to engineering behaviour. Bull Eng Geol Environ 74(4):1187-1211

44. Mohamed S, Mohsen M, Adel H (2008) Egyptian collapsible soils and their improvement. In: GeoCongress 2008, pp 654661

45. Osipov VI, Sokolov VN (1995) Factors and mechanism of loess collapsibility. In: Derbyshire E, Dijkstra T, Smalley IJ (eds) Genesis and Properties of Collapsible Soils. Springer Netherlands, Dordrecht, pp 49-63

46. Popescu ME (1986) A comparison between the behaviour of swelling and of collapsing soils. Eng Geol 23(2):145-163. https://doi.org/10.1016/0013-7952(86)90036-0

47. Rezaei M, Ajalloeian R, Ghafoori M (2012) Geotechnical properties of problematic soils emphasis on collapsible cases. Int J Geosci 3(1):105

48. Rogers CDF (1995) Types and distribution of collapsible soils. In: Genesis and Properties of Collapsible Soils. Springer, Dordrecht, pp 1-17

49. Rogers CDF, Dijkstra TA, Smalley IJ (1994) Hydroconsolidation and subsidence of loess: studies from China, Russia, North America and Europe: in memory of Jan Sajgalik. Eng Geol 37(2):83-113. https://doi.org/10.1016/0013-7952(94)90045-0

50. Skempton AW (1960) Terzaghi's discovery of effective stress. From Theory to Practice in Soil Mechanics: Selections from the Writings of Karl Terzaghi:42-53

51. Sun PP, Zhang MS, Zhu LF (2013) Typical case study of loess collapse and discussion on related problems. Geol Bull China 32(6):847-851

52. Tatsuoka F, Shibuya S (1992) Deformation characteristics of soils and rocks from field and laboratory tests. In: Proceedings of the 9th Asian Regional Conference on Soil Mechanics \& Foundation Engineering, vol 2, pp 101-170

53. Watts K, Charles JA (2015) Building on fill: geotechnical aspects. IHS BRE Press 
54. Wesley LD (2010) Fundamentals of soil mechanics for sedimentary and residual soils. Wiley. https://doi.org/10.1002/ 9780470549056

55. Wheeler S, Sharma R, Buisson M (2003) Coupling of hydraulic hysteresis and stress-strain behaviour in unsaturated soils. Géotechnique 53(1):41-54. https://doi.org/10.1680/geot.2003.53.1.41

56. Wyllie M, Gregory A, Gardner G (1958) An experimental investigation of factors affecting elastic wave velocities in porous media. Geophysics 23(3):459-493. https://doi.org/10.1190/1.1438493

57. Yun TS, Santamarina JC (2005) Decementation, softening, and collapse: changes in small-strain shear stiffness in $\mathrm{k} 0$ loading. J Geotech Geoenviron Eng 131(3):350-358. https://doi.org/10.1061/(ASCE)1090-0241(2005)131:3(350)

58. Zang A, Wong T-F (1995) Elastic stiffness and stress concentration in cemented granular material. Int J Rock Mech Mining Sci Geomech Abstr 32(6):563-574. https://doi.org/10.1016/0148-9062(95)00012-6

\section{Publisher's Note}

Springer Nature remains neutral with regard to jurisdictional claims in published maps and institutional affiliations.

Submit your manuscript to a SpringerOpen ${ }^{\odot}$ journal and benefit from:

- Convenient online submission

- Rigorous peer review

- Open access: articles freely available online

- High visibility within the field

- Retaining the copyright to your article

Submit your next manuscript at $\boldsymbol{\nabla}$ springeropen.com 